\title{
EL DIVINO NARCISO: ¿CONTRAFACTA DE ECOY NARCISO? ${ }^{1}$
}

\section{Adriana Cortés Koloffon}

Dirección de Literatura Coordinación de Difusión Cultural Zona administrativa exterior. Edificio «C» $3^{\text {er }}$ piso Ciudad Universitaria C.P. 04510. México D. F. México koloffon@lycos.com

[Anuario calderoniano (ISSN: 1888-8046), 4, 2011, pp. 55-77]

\section{La fábula de Narciso: del mito a la ficción}

En «The calderonian sources of El Divino Narciso by Sor Juana Inés de la Cruz", Alexander Parker se refiere a las principales fuentes del auto sacramental El Divino Narciso de la poetisa novohispana. Una de ellas es el drama Eco y Narciso, de Pedro Calderón de la Barca, inclui-

${ }^{1}$ El presente artículo constituye parte del tercer capítulo de mi tesis de doctorado titulada Cósmica y cosmética: los pliegues de la alegoría en "Eco y Narciso" de Calderón de la Barca, y en "El Divino Narciso", de sor Juana Inés de la Cruz, dirigida por la doctora Margo Glantz, profesora emérita de la Universidad Nacional Autónoma de México 
do en la cuarta parte de sus Comedias (1672). Basado en el mito de Narciso, recreado por Ovidio en las Metamorfosis, se representó en 1661 en Madrid. ¿Lo conoció la poetisa novohispana? Probablemente, a través de antologías y ediciones conmemorativas publicadas entre 1640 y $1675^{2}$.

La fábula de Narciso no aparece en literatura hasta comienzos de la era cristiana. La primera versión completa del mito se debe a Ovidio (43 a.C. -16 d.C.). De acuerdo con la investigadora sueca Louise Vinge, la fábula ovidiana es, debido a su gran riqueza descriptiva, "la fuente principal de los diversos escritores que han recreado el mito de Narciso", desde el siglo I a.C. hasta la actualidad ${ }^{3}$.

A partir del siglo XII, las Metamorfosis de Ovidio cobraron un auge notable que se prolongó hasta los siglos XVI y XVII. José María de Cossío encontró ocho poemas líricos, basados en el mito de Narciso narrado por Ovidio, que se publicaron en España entre 1591 y 1665; en opinión de Alexander Parker, todos ellos difieren del drama de Calderón, el cual constituye una de sus obras más relevantes ${ }^{4}$.

Otra derivación del mito fue, en el teatro áureo español, la comparación de Narciso con Cristo establecida por Andrés de Villamayor y Diego de Nájera y Zegrí, autores cuyos autos titulados Eco y Narciso, desde la perspectiva de Parker, no alcanzan la imaginación poética que revela sor Juana en El Divino Narciso; asimismo, la alegorización que hacen estos escritores es muy distinta de la presentada por la jerónima en su auto $^{5}$. Sobresale por su originalidad el libro de Jacobus Masenius, titulado Speculum Imaginum Veritatis Occultae, exhibens Symbola, Emblemata, Hieroglyphica, Aenigmata (1650), donde Narciso representa un símbolo de Cristo. A diferencia de otras obras de los siglos XVI y XVII — con excepción del auto de la jerónima y de un poema de Pierre de Marbeuf dedicado a la Virgen María-, en las cuales el espejo en el que se mira Narciso se asocia con el tema de la vanidad, en el Speculum de Masenius éste presenta connotaciones positivas en relación con la pureza de la Virgen y la encarnación de Cristo,

${ }^{2}$ Ver Parker, 1968, p. 259.

${ }^{3}$ Vinge, 1967, p. 11, trad. del sueco al inglés por Robert Dewsnap. La traducción del inglés es mía.

${ }^{4}$ Ver Parker, 1968, p. 261.

${ }^{5}$ Ver Parker, 1968, p. 263. 
simbolismo ampliamente difundido en el ocaso de la Edad Media ${ }^{6}$. ¿Leyó sor Juana la obra mencionada del jesuita alemán? No se sabe con exactitud, aunque el libro se publicó mucho antes de que aparecieran la loa y el auto de la monja en el segundo tomo de sus Obras Completas en 1693, y era popular en Nueva España 7.

¿Qué retoma la jerónima de Eco y Narciso, de Calderón de la Barca? Julio Jiménez Rueda, Emilio Carilla, Alfonso Méndez Plancarte y Louise Vinge coinciden en que este drama representa la principal fuente de El Divino Narciso; en cambio, al parecer de Alexander Parker, si bien el auto presenta influencias evidentes, tanto estructurales como estilísticas de la pieza teatral citada, el tratamiento que la jerónima hace del mito de Narciso se basa en El Divino Orfeo — auto sacramental de Calderón de la $\mathrm{Barca}^{8}$ - y, sobre todo, en la primera parte de los autos publicados por Calderón en 1677.

Durante el siglo XVI se difundieron numerosas versiones moralizadas del mito de Narciso, algunas de ellas escritas durante el siglo XIV. A estas obras recreadas a lo divino, a partir de un texto profano, se les conoce con el nombre de contrafactae. Entre las más divulgadas se encuentran el Ovide moralisé, una traducción al francés de las Metamorfosis, de autoría incierta, y Ovidius moralizatus, de Petrus Berchorius, escrito en latín. En el Ovide moralisé, el amor triunfa sobre la vanidad de Narciso ${ }^{9}$. En estas versiones del mito de Narciso, así como en la Filosofía secreta de Juan Pérez de Moya ${ }^{10}$, el episodio del reflejo se utiliza para mostrar el peligro de los placeres mundanos.

El latinismo contrafactum, término compuesto acuñado por Bruce Wardropper a partir de las fórmulas en castellano (vuelto o contrahecho a lo divino) y en alemán (die geistliche Kontrafaktur o contrahechura espiritual), designa a las obras profanas trasladadas a lo divino ${ }^{11}$. La Edad de Oro de las contrafactae tuvo lugar en Francia, durante el siglo

${ }^{6}$ La oda de Pierre de Marbeuf a la que Vinge hace referencia se publicó en 1620. Corresponde a una serie sobre la Inmaculada Concepción, y lleva por subtítulo: $L e$ tableau de Narcisse. En este poema la Virgen representa un Pozo de aguas puras donde Dios se refleja. Ver Vinge, 1967, pp. 189-190, 226-227.

${ }^{7}$ Ver Osorio, 1989, p. 158.

${ }^{8}$ Ver Parker, 1968, pp. 264, 269.

${ }^{9}$ Ver Vinge, 1967, pp. 91-115.

${ }^{10}$ Ver Pérez de Moya, Filosofía secreta, p. 586.

${ }^{11}$ Ver Wardropper, 1958, pp. 5-6. 
XIII, y en España, Alemania e Italia a fines del XV y todo el XVI ${ }^{12}$. No obstante, el autor de Historia de la poesía lírica a lo divino en la cristiandad occidental, menciona en su libro varios ejemplos de éstas producidas en España, en el siglo XVII. Prevalecen entonces las interpretaciones del mito de Narciso influidas por el neoplatonismo renacentista, igual que las contrafactae del mismo, entre las cuales puede mencionarse, el Teatro de los Dioses de la Gentilidad de Baltasar de Vitoria que advierte acerca de los riesgos del amor propio en exceso.

Una contrafacta o divinización es, a juicio de Wardropper, «una obra literaria (a veces una novela o un drama, pero generalmente un poema lírico de corta extensión) cuyo sentido profano ha sido sustituido por otro sagrado". Se trata de una refundición que a veces "conserva del original el metro, las rimas, y aun - siempre que no contradiga al propósito divinizador - el pensamiento». El nombre de la dama amada «se sustituye con el de la Santa Virgen; lo erótico se convierte en el amor cristiano" ${ }^{13}$. La consolidación de las contrafactae coincide con el auge de la devotio moderna; ambas, según el investigador, llenaron el vacío espiritual causado por el desmoronamiento de los ideales medievales.

Desde la perspectiva del investigador, la divinización de temas lleva inevitablemente, en su forma más concentrada, a la alegoría. El creador de contrafactae elige un tema profano que desarrolla extensamente, para ilustrar una idea asociada con la tradición cristiana.

Me pregunto: ¿El Divino Narciso es una contrafacta de Eco y Narciso? Alfonso Méndez Plancarte sostiene que la monja, al recrear el mito de Narciso a lo divino, incluye en su obra literales citas implícitas del drama de Calderón. Louise Vinge, quien reconoce asimismo una gran influencia de esta pieza teatral del dramaturgo, en el auto de la poetisa, advierte que el entorno pastoril recreado por su autor en Eco y Narciso, le permitió "establecer la conexión con la alegoría del auto: Narciso-Cristo se transforma en el Buen Pastor que busca a su oveja». De igual modo, Vinge resalta las semejanzas entre el personaje de Eco en ambas piezas teatrales: «Podría decirse que el Ángel Caído de Juana Inés representa al personaje de Eco, según el modelo de Cal-

12 Ver Wardropper, 1958, p. 7.

13 Wardropper, 1958, p. 6. 
derón, más que el de Ovidio ${ }^{14}$ ». Por último, menciona ciertos momentos dramáticos que, desde su perspectiva, le permitieron identificar a Narciso con Cristo: las escenas del terremoto y del eclipse solar, así como de la tentación, en Eco y Narciso remiten, en efecto, a los pasajes análogos del Nuevo Testamento. La autora de The Narcissus theme in Western European literature up to the 19th century concluye que el drama de Calderón le ofreció a sor Juana la posibilidad de adaptar con mayor facilidad el tema de Narciso como una imagen de Dios enamorado de su propio reflejo - Naturaleza Humana, a la cual crea a su semejanza-, que si lo hubiera hecho a partir de la fábula de Ovidio ${ }^{15}$. Parker difiere de Vinge en cuanto a las coincidencias temáticas de las dos obras: «Si bien El Divino Narciso y Eco y Narciso presentan el mismo argumento, en términos generales, el tema en ambas piezas teatrales es tan distinto, que no puede considerarse a la primera una contrafacta del drama». El auto de la monja novohispana es, en opinión del investigador, «una versión a lo divino del mito, y no del tratamiento que Calderón hace de éste ${ }^{16}$ ".

Establezco aquí una comparación de los momentos dramáticos más relevantes en El Divino Narciso y en Eco y Narciso.

2. Semejanzas y diferencias de algunos momentos dramáticos en ECo y Narciso y en El Divino Narciso

En el cuadro 1 enumero los momentos dramáticos más relevantes en ambas piezas teatrales, que presentan un gran parecido. La enumeración sigue un orden cronológico hasta la muerte de Narciso.

${ }^{14}$ Vinge, 1967, p. 246.

15 Vinge, 1967, p. 247.

16 Parker, 1968, p. 261. 


\begin{tabular}{|c|c|c|}
\hline & ECO Y NARCISO & EL DIVINO NARCISO \\
\hline 1. & $\begin{array}{l}\text { Los pastores buscan a Narci- } \\
\text { so, a quien Liríope, su madre, } \\
\text { deja en la cueva mientras va al } \\
\text { monte a cazar. Cuando Narciso } \\
\text { oye la voz de Liríope, sale de la } \\
\text { cueva y escucha las voces de los } \\
\text { pastores, quienes intentan atraer- } \\
\text { lo por medio de sus cantos. }\end{array}$ & $\begin{array}{l}\text { Gentilidad y Sinagoga llaman a } \\
\text { Narciso, a petición de Naturaleza } \\
\text { Humana, madre de ambas, para que } \\
\text { intercedan por ella y obtenga su } \\
\text { perdón por haber cometido la Falta } \\
\text { Original. Estos dos personajes cantan } \\
\text { para invocar la presencia de Narciso. }\end{array}$ \\
\hline 2. & $\begin{array}{l}\text { Eco sube al monte con el ob- } \\
\text { jeto de declararle su amor a Nar- } \\
\text { ciso; canta, mientras le ofrece } \\
\text { como regalo el valle que es de su } \\
\text { propiedad. }\end{array}$ & $\begin{array}{l}\text { Eco sube al monte para declararle } \\
\text { su amor a Narciso y cantando le } \\
\text { propone regalarle los valles, el ganado } \\
\text { y el océano que le pertenecen. }\end{array}$ \\
\hline 3. & $\begin{array}{l}\text { Eco enmudece debido a un } \\
\text { veneno que le suministra Lirío- } \\
\text { pe. Su mudez se manifiesta } \\
\text { cuando intenta decirle a Narciso } \\
\text { que la imagen que ve reflejada } \\
\text { sobre la superficie del agua de } \\
\text { una fuente es la de él, y no la de } \\
\text { una ninfa, de quien se enamora. }\end{array}$ & $\begin{array}{l}\text { La mudez de Eco es provocada } \\
\text { por la envidia que le causa ver a } \\
\text { Narciso contemplando la imagen de } \\
\text { Naturaleza Humana sobre las aguas } \\
\text { cristalinas de la Fuente. Narciso des- } \\
\text { deña a Eco y se enamora de Natura- } \\
\text { leza Humana. }\end{array}$ \\
\hline 4. & $\begin{array}{l}\text { El deseo de Eco de darse } \\
\text { muerte, provocado por el desdén } \\
\text { de Narciso, de quien está ena- } \\
\text { morada. Fco se transforma en } \\
\text { aire y se eleva. }\end{array}$ & $\begin{array}{l}\text { El intento de suicidio de Eco, } \\
\text { cuando ve que Narciso contempla la } \\
\text { imagen de Naturaleza Humana sobre } \\
\text { el agua cristalina de la Fuente. Sus } \\
\text { atributos: Soberbia y Amor Propio la } \\
\text { esconden en el tronco hueco de un } \\
\text { árbol y se transforma en aire. }\end{array}$ \\
\hline 5. & $\begin{array}{l}\text { Se oye el ruido de un terre- } \\
\text { moto, según las acotaciones } \\
\text { escénicas. Narciso muere, cae al } \\
\text { suelo y se transforma en flor. }\end{array}$ & $\begin{array}{l}\text { Muere Narciso: se escucha el rui- } \\
\text { do de un terremoto, de acuerdo con } \\
\text { las acotaciones escénicas. Transfor- } \\
\text { mado simbólicamente en una Hostia, } \\
\text { aparece sobre un Cáliz en el carro de } \\
\text { la Fuente. }\end{array}$ \\
\hline
\end{tabular}




\subsection{La búsqueda de Narciso: cruce de identidades}

En el primero de estos pasajes, al que hago referencia en el cuadro anterior, los pastores buscan a Narciso quien huye de la cueva donde Liríope, su madre, lo había dejado antes de salir a cazar. Los pastores cantan, en Eco y Narciso, mientras pronuncian los siguientes versos:

LAURA

NISE

LAURA

NisE

SIRENE

$\mathrm{ECO}$

LIRÍOPE

ELLA, Música

Y TODOS
Canta. Pues del monte la falda

tocó a mis voces,

díganme de Narciso

fuentes y flores.

Canta. Pues a mí de la selva

tocó lo alegre,

de Narciso me digan

flores y fuentes.

[...]

¡A la falda!

¡A la selva!

¡A la cumbre!

¡Al risco!

Oiga a todos y todas decir...

¡Narciso!

¡A la falda, a la selva,

a la cumbre, al risco! (p. 1916)

He aquí el pasaje análogo de El Divino Narciso:

GENTILIDAD

Coro 2

SinAgOga

GentilidAD

SinAgOga

GENTILIDAD
¡Aplaudid a Narciso, Fuentes y Flores!

$\mathrm{Y}$ pues su beldad divina, sin igualdad peregrina, es sobre toda hermosura, que se vió en otra criatura, $\mathrm{y}$ en todas inspira amores, ¡alabad a Narciso, Fuentes y Flores! ¡Alabad, aplaudid,

con himnos,

\footnotetext{
con voces,
} 
SiNAGOGA

Gentilidad

SinAgOga

Gentilidad al Señor,

a Narciso,

todos los Hombres,

En los versos citados del auto, Gentilidad y Sinagoga, que representan tanto a la cultura y a la religión grecorromana como a la hebrea, respectivamente, invocan a Narciso mediante una serie de cantos, con el objeto de que redima a Naturaleza Humana - madre de ambas-, por haber cometido la falta original. La dimensión religiosa de esta invocación es evidente en la alusión hecha por Sinagoga y Gentilidad a la «beldad divina» de Narciso.

En el drama, la búsqueda de Narciso quizá presenta, asimismo, un trasfondo religioso; este personaje acaso simboliza al hombre encadenado en el interior de la cueva, a causa de la falta original. Cuando sale, Narciso se encuentra solo, perdido en el bosque, ámbito opuesto a la Arcadia asociada con el Paraíso. La gruta, a decir de Ignacio Arellano, simboliza el estado irracional y ciego del hombre, privado de la luz de la Gracia, abortado por el útero de la tierra y recogido en la tumba de la misma materia: es a la vez cuna y sepultura, «muestra de la debilidad y grosera condición del hombre sometido a sus instintos» ${ }^{17}$.

Hogar y prisión de Narciso, la cueva presenta múltiples connotaciones simbólicas y alegóricas en las piezas teatrales de Calderón. John E. Varey advierte cómo en algunas obras del dramaturgo, los salvajes, vestidos de pieles, habitan en las cuevas. Un ejemplo representativo es el personaje de Semíramis, «fiera racional», en La hija del aire. En El mágico prodigioso (estrenado en 1637), la cueva se asocia asimismo con el ámbito salvaje; constituye, según Varey, «la imagen de un ataque al orden divino, el centro de un culto secreto del poder orientado a la destrucción de la armonía del mundo creado por Dios» ${ }^{18}$.

Los habitantes de la Arcadia, en Eco y Narciso, se desplazan hacia un ámbito caótico, cruzan la frontera simbólica que separa a la selva armoniosa del monte donde habitan Narciso y Liríope. Tal vez sea posible asociar este acto, en términos simbólicos, con el pensamiento

17 Arellano, 2000a, p. 170.

${ }^{18}$ Varey, 1987, pp. 253, 256. 
del hombre barroco en el umbral de la modernidad. En El salvaje en el espejo, Roger Bartra explica que durante el siglo XVI «los impulsos por definir la identidad del hombre moderno y civilizado aumentaron considerablemente, espoleados por las grandes transformaciones sociales y políticas, y por el impacto que tuvo en la inteligencia europea el conocimiento y la colonización del Nuevo Mundo" ${ }^{19}$.

Liríope y Narciso, en el drama de Calderón, errores de la Naturaleza, desde la perspectiva aristotélica prevaleciente en el siglo XVII, ¿no revelan a los pastores de la Arcadia su faceta indómita? Eco expresa el deseo de visitar, en su aniversario, el templo de Júpiter (separado de la Arcadia por una frontera invisible) situado en el monte donde se esconde el "horrible monstruo fiero" (p. 1908).

Los pasajes anteriores son parecidos en cuanto a sus características formales y simbólicas: se trata, a mi juicio, de una búsqueda que intenta lograr la salvación espiritual de Gentilidad y Sinagoga, en El Divino Narciso, y de Narciso, en el drama de Calderón. Con todo, Narciso quizá también redima a los pastores de la Arcadia, siguiendo a Bartra: el hombre salvaje es redentor — apunta el antropólogo- «no porque proponga un viaje al pasado, a la Edad de Oro perdida, sino porque es capaz de ser conscientemente primitivo para transformar al mundo que lo rodea en una realidad moderna ${ }^{20}$. Durante el Renacimiento, explica, el mito del salvaje «va adquiriendo cada vez más claramente un carácter nuevo: ya no sólo como una reflexión sobre los vínculos entre la naturaleza y la cultura", sino además, "como una crítica a la civilización, a veces incluso como una trágica comprobación con que la modernidad amenaza al hombre ${ }^{21}$. El salvaje, eco del hombre civilizado, le recuerda de manera constante su estado primigenio, natural, en el drama Eco y Narciso; tal vez por esta razón suscite en él un temor ineludible ante las fuerzas irrefrenables de la naturaleza y, al mismo tiempo, el deseo de recuperar la unidad con un estado natural semejante al Paraíso, en el Antiguo Testamento. Agazapado en el imaginario del hombre occidental, el salvaje lo acecha. El tema de Eco y Narciso examinado desde la perspectiva del umbral de

19 Bartra, 1992, p. 170. En su libro, el antropólogo analiza el mito del salvaje en distintas tradiciones, a lo largo de la historia.

${ }^{20}$ Bartra, 1992, p. 188.

21 Bartra, 1992, p. 170. 
la modernidad en el siglo XVII merece un estudio mucho más amplio $^{22}$.

\title{
2.2. Eco enamorada de Narciso
}

En el drama, Eco sube al monte para declararle su amor a Narciso. Así lo expresa:

\author{
Bellísimo Narciso, \\ que a estos amenos valles \\ del monte en que naciste, \\ las asperezas traes, \\ mis pesares escuchas, \\ pues deben obligarte, \\ cuando no por ser míos, \\ solo por ser pesares. \\ [...] \\ Eco soy, la más rica \\ pastora de estos valles; \\ bella decir pudieran \\ mis infelicidades; \\ que de amor en el templo, \\ por culto a sus altares, \\ de felices bellezas \\ pocas lámparas arden. \\ Todo aquese oceano \\ de vellones, que hace \\ con las ondas de la lana \\ crecientes y menguantes, \\ desde aquella alta roca \\ hasta este verde margen, \\ esmeraldas paciendo \\ y bebiendo cristales, \\ todo es mío; [...] \\ [...] \\ Todo a tus pies lo ofrezco; \\ y no porque a rogarte
}

22 Regalado examina el tema en esta y otras obras de Calderón, en Los orígenes de la modernidad en la España del Siglo de Oro, 1995. 
lleguen hoy mis ternezas, imágenes que nacen en la constancia mía de usadas liviandades, supuesto, bello joven, que no puede obligarme, sino es de ser tu esposa, a que mi amor declare. (p. 1925)

En El Divino Narciso, Eco también sube al monte donde se encuentra Narciso. Igual que el personaje homónimo, en el drama, canta en tono recitativo, según las acotaciones, los siguientes versos y le confiesa su amor:

Bellísimo Narciso,

que a estos humanos valles, del Monte de Tus glorias

las celsitudes traes:

mis pesares escucha,

indignos de escucharse,

pues ni aun en esto esperan

alivio mis pesares.

Eco soy, la más rica

Pastora de estos valles;

bella decir pudieran

mis infelicidades.

[...]

$\mathrm{Y}$ pues el interés

es en todas edades

quien del Amor aviva

las viras penetrantes,

tiende la vista a cuanto

alcanza a divisarse

desde este monte excelso

que es injuria de Atlante.

[...]

Mira de uno a otro Polo

los Reinos dilatarse,

dividiendo regiones

los brazos de los mares,

y mira cómo surcan 


\begin{abstract}
de las veleras naves
las ambiciosas proas sus cerúleos cristales.

$[\ldots]$

Todo, bello Narciso, sujeto a mi dictamen, son posesiones mías, son mis bienes dotales. Y todo será Tuyo, si Tú con pecho afable depones lo severo y llegas a adorarme.
\end{abstract}

(vv. 707-718; 743-750; 783-790; 795-802)

Incluyo aquí los pasajes de Eco Narciso y de El Divino Narciso, pese a su extensión, con el objeto de mostrar su gran parecido. Evidentemente, los versos de Calderón constituyen un espejo donde se reflejan los versos de sor Juana trasladados a lo divino, para alegorizar la tentación del Demonio a Cristo en el desierto, a la cual hace referencia el Nuevo Testamento. Considero relevante destacar que, en las dos obras, Eco canta los pasajes mencionados; a diferencia de Narciso en la pieza teatral de Calderón, Narciso-Cristo, en el auto, no se deja seducir por el canto de Eco, análogo al de las sirenas que sumergen en la locura a los navegantes en la Odisea ${ }^{23}$.

El monte presenta connotaciones bíblicas, tanto del Antiguo como del Nuevo Testamento (Éxodo, 3, 1-13; Mateo, 5, 1-11; Mateo, 26, 30; Marcos, 3, 13) y se asocia con lo sagrado, en El Divino Narciso; constituye el vínculo entre la tierra y el cielo, lo corpóreo y lo espiritual. Es el lugar donde Narciso-Cristo observa el mundo (según las acotaciones escénicas, Narciso se encuentra en la cima) y se resiste a la tentación de Eco, quien caracteriza a Naturaleza Angélica Réproba. En cambio, en Eco y Narciso, el monte se relaciona con el desorden del cosmos, igual que en otras obras de Calderón; menciono sólo tres de ellas: El mágico prodigioso, La vida es sueño y La hija del aire. En el esquema simbólico del dramaturgo, el monte representa, a decir de

${ }^{23}$ La sirena, de acuerdo con Alciato, «es mujer seductora, que acaba en oscuro pez, como muchos monstruos que trae consigo el deseo» (ver Alciato, emblema CXV, p. 152). 
Melveena McKendrick, «la falta de control y razón, la impotencia, el peligro, un abanico de cosas indeseables que en términos generales se diferencia muy poco del simbolismo medieval ${ }^{24}$.

Ignacio Arellano destaca el valor alegórico de este espacio dramático en numerosas obras de Calderón ${ }^{25}$, donde simboliza la ruptura de la armonía cósmica, la naturaleza corrompida después del pecado original en el que participa toda la naturaleza, de acuerdo con el relato del Génesis. Dijo Dios a Adán: «Por haber escuchado la voz de tu mujer y comido del árbol del que yo te había prohibido comer, maldito sea el suelo por tu causa: con fatiga sacarás de él el alimento todos los días de tu vida" (Génesis, 3, 17). En el auto sacramental La piel de Gedeón, la aspereza inculta es un rasgo del monte, lugar de los sacrificios idólatras a $\mathrm{Baal}^{26}$; asimismo, en el drama mencionado de Calderón, en el monte se encuentra el templo de Júpiter hacia donde se desplazan los pastores de la Arcadia en el aniversario de Eco, quien manifiesta haberse consagrado al dios romano relacionado con el paganismo, según la tradición cristiana.

De acuerdo con María Teresa Cattaneo, las correlaciones simbólicas del monte son múltiples en las obras del dramaturgo. Puede reducirse "de momento al área breve de la torre / cueva / prisión" (es el caso de Segismundo, en La vida es sueño, o de Semíramis, personaje de La hija del aire, quien habita en una cueva a la que compara con una prisión); es, asimismo, el lugar de la aventura: en ocasiones «es búsqueda de soledad, de penitencia, de la verdad" o de la búsqueda espiritual; en el monte «pueden hacerse los encuentros más sorprendentes». Espacio polimórfico y móvil, ofrece a sor Juana igual que a

${ }^{24}$ McKendrick, 1990, pp. 128-129. La investigadora destaca la asociación entre el monte y la humillación sexual y social de la mujer, en El alcalde de Zalamea; lo mismo puede decirse de Eco y Narciso, donde Liríope es violada por Céfiro en el monte y de La hija del aire, cuando Arceta es violada por el aire que engendra en ella a Semíramis.

${ }^{25}$ Arellano menciona como ejemplo, el auto A María el corazón donde la montaña agreste es el territorio de los bandoleros y de la hidra, símbolo apocalíptico. «La Sencillez en Psiquis y Cupido (Madrid) se ha perdido en la maleza de un monte en el que solo halla "bestias, monstruos y vestiglos"” (ver Arellano, 2000a, pp. 165-166).

${ }^{26}$ Ver Arellano, 2000a, pp. 164-165. En otro drama de Calderón, titulado Fieras afemina amor, el monte, ámbito relacionado con las fuerzas irracionales de la naturaleza también es limítrofe con el bosque, entorno que simboliza el orden, el decoro, en esta pieza teatral del dramaturgo. 
Calderón, una amplia posibilidad de dinamismo, evidente en ambas piezas teatrales: lugar de la revelación, espacio teofánico cercano al cielo que simboliza la morada de Dios, en el auto, el monte constituye en Eco y Narciso el espacio de la caída simbólica del hombre, cubierto tan sólo por pieles, las cuales denotan un estado de desnudez metafórica ${ }^{27}$.

\title{
2.3. El silencio de Eco
}

Liríope, a quien el adivino Tiresias profetiza que Narciso morirá a causa de una hermosura y una voz, le suministra un veneno a Eco con la intención de enmudecerla, y que su hijo no se enamore de ella. Cuando ve a Narciso contemplando su propia imagen sobre la superficie de una fuente, Eco piensa cobrar venganza: intenta decirle que ésta no es la de una ninfa, como él lo cree.

Tanto en el drama, como en el auto, Eco enmudece en el momento preciso en que observa a Narciso contemplar la imagen de una ninfa, en el primero, y de Naturaleza Humana, de quien se enamora, en el segundo. En la pieza teatral de Calderón, Eco, soberbia, intenta cobrar venganza ante el desdén de Narciso; así lo manifiesta:

\author{
¡Oh, si el dolor me dejara \\ aliento con que pudiera \\ desengañar tu ignorancia, \\ para tomar de una vez \\ de tu vanidad venganza! (p. 1934)
}

En El Divino Narciso, la mudez de Eco presenta, además, una conexión con los atributos de este personaje: Soberbia y Amor Propio, quienes son sus acompañantes a la vez. El dolor y la envidia hacia Naturaleza Humana provocados por el hecho de saber que Narciso se enamora de ella, se expresan mediante un juego de ecos, metáfora dramática del pecado de soberbia. Escondida en el tronco hueco de un árbol, según las acotaciones, Eco repite las últimas palabras de Narciso:

${ }^{27}$ Ver Cattaneo, 2003, p. 130. 


$\begin{array}{ll}\text { Narciso } & \text { Mas ¿quién, en el tronco hueco, } \\ \text { Eco } & \text { Eco. } \\ \text { Narciso } & \text { con triste voz y quejosa, } \\ \text { Eco } & \text { Quejosa. } \\ \text { NARciso } & \text { así a mis voces responde? } \\ \text { Eco } & \text { Responde. (vv. 1648-1653) }\end{array}$

En un pasaje de Eco y Narciso similar al citado, Narciso le asegura a Eco que, no obstante que ella muera celosa de la supuesta ninfa, él no la amará:

NARCISO

LIRÍOPE

NARCISO

ECO

NARCISO

ECO

NARCISO

ECO

NARCISO

ECO
¿Quién a mi voz respondió?

Eco, a quien el monte esconde, que a cuanto escucha responde.

¿Y a sí no perdonó?

[Dentro.] No.

Pues, Eco, oye. Aunque tú mueras...

[Dentro.] Mueras...

... celosa, yo enamorado...

[Dentro.] ... enamorado...

... no me he de acordar de ti.

[Dentro.] ... de ti. (p. 1938)

Tanto en el drama, como en el auto, la mudez de Eco presenta matices religiosos asociados con la Caída. En la pieza teatral de Calderón, la mudez de Eco es "parto del opio y beleño", en palabras de Liríope; su efecto es mortal, pues «tan eficazmente hiere, / que no será menester / que le beba; que le pise / bastará, para correr / brevemente al corazón / por el contacto del pie» (p. 1931). Liríope es acaso equiparable a la serpiente en la Biblia, símbolo de falsedad, de astuta malignidad y de peligro mortal en diversos pasajes (Génesis, 3, 1, 48, 17; Salmos, 140, 4; Mateo, 3, 7; 23, 33; Proverbios, 23, 32...). El veneno penetra en la vanidosa pastora a través de la parte más baja del cuerpo: el pie, relacionada con lo terreno, lo pecaminoso, para desplazarse después hacia su corazón, asiento de la vida psíquica, afecti- 
va, intelectual, volitiva, moral y física ${ }^{28}$. Corazón y sangre: conceptos sinónimos en el Antiguo Testamento (Levítico, 17, 11); en el Nuevo, es el punto de partida del bien y del mal (Mateo, 5, 8, 15, 19).

El género del auto exige, evidentemente, la inserción de este motivo dramático - la mudez de Eco- en una dimensión teológica. El corazón envenenado de la pastora, en el drama, deviene, quizá, a lo divino, una metáfora de la Falta Original: los borrones ensucian la imagen de Naturaleza Humana y le impiden el encuentro con Dios. La mudez de Eco adquiere asimismo tintes teológicos relacionados con la soberbia que alentó en Luzbel, el más perfecto entre los ángeles creados por Dios, el deseo de asemejarse a Él: la envidia de EcoNaturaleza Angélica Réproba hacia Naturaleza Humana, en El Divino Narciso, remite, en efecto, al pasaje del Antiguo Testamento alusivo a la soberbia del rey de Babilonia, texto identificado por los estudiosos de la Biblia con la caída de los ángeles (Isaías, 14, 12-17). Con todo, en términos teológicos, la soberbia de Luzbel no está por completo desvinculada de la del hombre. De acuerdo con Santo Tomás de Aquino, el pecado del primer hombre fue de soberbia, la cual le indujo a desobedecer los mandatos de Dios $^{29}$.

Prisionera de su propio reflejo, el castigo de Eco, en el drama y en el auto, es la muerte análoga al silencio.

\subsection{Eco intenta suicidarse}

En el mito narrado por Ovidio, Eco, dolida por el rechazo de Narciso "pierde todo jugo", y de ella sólo quedan "huesos y voz, y luego nada más que voz»; sus huesos se vuelven "piedra" ${ }^{30}$. En cambio, tanto en el drama como en el auto, Eco intenta quitarse la vida por cuenta propia. En Eco y Narciso, Febo le propone curarla, después de que enmudece; tras rechazar la propuesta de su enamorado, pretende arrojarse al vacío, desde lo alto del monte. Así lo expresa:

28 Diccionario de la Biblia, p. 375.

${ }^{29}$ Santo Tomás de Aquino, Summa, 2-2, 105, 2 ad. 3; 162, 4, citado por Arellano en 2000b, p. 205.

30 Ovidio, Las metamorfosis, p. 136. 
ECO
[Para sí, o por señas.]
Y para que no lo logres, desesperada a ese centro me he de arrojar. (p. 1939)

De acuerdo con las acotaciones, mientras Febo tiene asida a Eco, ésta vuela a lo alto, transformada en aire. En El Divino Narciso, es Amor Propio, quien hace referencia al intento de suicidio de Eco:

$\begin{array}{ll}\text { AMOR PROPIO } & \text { Mira, que juzgo que precipitada } \\ & \text { quiere arrojarse, del furor llevada; } \\ & \text { ¡tengámosla! }\end{array}$

SOBERBIA

Tenerla solicito, aunque yo soy quien más la precipito. (vv. 1466-1469)

Según las acotaciones escénicas, Amor Propio y Soberbia, a la vez cómplices y atributos de Eco, la detienen para impedir su suicidio, y ella «hace como que quiere arrojarse». Amor Propio y Soberbia quizá podrían ser, asimismo, los atributos de Liríope, en el drama, quien intenta evitar que su hijo Narciso se enamore de Eco. En el auto, los compañeros de Eco-Naturaleza Angélica Réproba, la esconden en el tronco hueco de un árbol cuando les refiere la causa de su dolor: la preferencia de Narciso hacia Naturaleza Humana.

Son múltiples las connotaciones simbólicas de esta alegoría escénica omitida en Eco y Narciso, en diversas tradiciones. Relacionado con el Sacramento de la Eucaristía en el auto, el árbol simboliza tanto la Caída, como la redención de Naturaleza Humana. En efecto, J. Petelin destaca la forma en que las connotaciones negativas de la Sabiduría, simbolizada por el Árbol de la Ciencia del Bien y del Mal, se transforman en positivas, en relación con el conocimiento de Dios y la fe, en los Proverbios: "En los sabios se manifiesta un progreso de la Revelación al presentar a la Sabiduría-Maestra universal y al usar los mismos símbolos que usa el Génesis, pero con significado positivo, constructivo: "La Sabiduría" es fruto de la vida, o mejor, "fuente de vida" (Proverbios, 13, 14; 16, 22; 18, 4) y es "árbol de vida para quien la consigue; quien la abraza es bienaventurado" (Proverbios, 3, 18)" ${ }^{31}$. La

31 Petelin, 1984, p. 347. En la Biblia, la alusión a los árboles no es exclusiva del Génesis; también en otros libros, entre otros el de los Proverbios, se hace mención de 
polivalencia de este símbolo se percibe en El Divino Narciso, donde el Árbol de Muerte lo es también de Vida: en el interior de su tronco, donde se esconde Eco, se ocultan asimismo Gracia y Naturaleza Humana, quien desde allí se asoma a la superficie de las aguas de la Fuente, donde Narciso ve su imagen reflejada. La muerte de NarcisoCristo y la salvación de Naturaleza Humana son representadas así en el espacio dramático.

De igual modo, quizá el árbol, en la obra de la jerónima, pueda compararse con un eje cósmico donde confluyen los tres mundos: el inferior o infernal, simbolizado por Eco (Naturaleza Angélica Réproba); el central o terrestre, por Naturaleza Humana; y el superior o celeste, por la copa del árbol que toca el cielo, en oposición a las raíces hundidas en la tierra. El tronco representa el puente de unión de los opuestos: del inframundo y del cielo que representan el mal (la muerte) y el bien (la vida), respectivamente ${ }^{32}$.

Tanto en el drama, como en el auto, Eco no muere: sólo se transforma en aire siguiendo el mito de Narciso narrado por Ovidio. La identificación de este elemento con los espíritus malignos procede de una creencia griega, según la cual el espíritu de los difuntos posee alas. Más tarde, los pitagóricos se refirieron a la existencia en el aire de múltiples almas asociadas con los demonios. Al parecer de Platón, los demonios, ciudadanos del viento, suceden a los dioses en rango jerárquico. En la Epístola a los Efesios, san Pablo, bajo la influencia de la tradición griega, sostiene que el Demonio es «el príncipe del imperio del aire" ${ }^{33}$.

Los matices negativos del viento, asociados con el relato bíblico del Génesis, son evidentes en Eco y Narciso y en El Divino Narciso, donde éste encarna en personajes que suscitan una tragedia. En el drama, Liríope expresa cómo Céfiro «hijo del viento sutil» la eleva por el aire hasta la cumbre altiva del monte donde la viola: «Viéndome desvanecer / al solicitar medir / la distancia de la tierra, / los ojos cer-

ellos en un sentido simbólico: La felicidad del sabio: «Es árbol de vida para los que se aferran a ella, / felices son los que la retienen» (Proverbios, 3, 18).

${ }^{32}$ Ver Cirlot, 1997, pp. 89-92.

33 San Pablo se refiere así al poder del Demonio: «Y vosotros que estabais muertos en vuestros delitos y pecados, en los cuales vivisteis en otro tiempo según el proceder de este mundo, según el príncipe del imperio del aire, el espíritu que actúa en los rebeldes» (Efesios, 2, 2). 
ré, y me así / al traidor hijo del viento: ¡Ah, qué abrazo es tan rüin / el que la necesidad / hace dar y no sentir!» (p. 1913).

Las palabras pronunciadas por el Demonio, disfrazado de serpiente en el Génesis bíblico, se desplazan por el aire y provocan la Caída de Eva, cuando la incitan a comer el fruto del Árbol de la Ciencia. Eco, en el drama, representa el sonido impuro, corrompido, la naturaleza degradada, como la de Liríope a causa de la violación. El eco, metaforizado en el personaje de Eco, en el auto, se opone a la palabra articulada, al Verbo encarnado en Narciso-Cristo que restablece la armonía entre el hombre y el Creador, según la tradición cristiana. Demonio aéreo, "príncipe del imperio del aire", según san Pablo, Eco, en el auto, intenta arrojarse al precipicio sin morir (el Demonio nunca muere). Se lo impiden sus eternos compañeros: Soberbia y Amor Propio. Vivirá por siempre en el abismo «sólo / al dolor, muerta al alivio" (vv. 2197-2198).

\subsection{Narciso enamorado de sí mismo}

En el drama, Narciso ve a una ninfa de quien se enamora sin saber que es su propio reflejo. Liríope intenta desengañar a su hijo mediante el acto de reflejarse ella misma sobre la superficie de las aguas, donde él ve a la supuesta ninfa. Cito aquí este pasaje:

LiRíope

NARCISO

LiRÍOPE

NARCISO

LiRÍOPE
¿Estoy en el agua yo ahora, Narciso?

No.

Ahora llega Liríope.

$\mathrm{Y}$ ahora ¿estoy en ella?

Sí,

y equívoco mi deseo, extraños discursos fragua, cuando en la tierra y el agua a un mismo tiempo te veo.

Pues de esa misma manera que a mí me miras, te ves. La que juzgas deidad es sombra tuya. Considera 
si ha sido tu amor locura, pues a sí mismo se amó. (p. 1938)

De la sombra de Narciso evocada por Liríope en los versos anteriores, a Naturaleza Humana, a quien Narciso ve reflejada sobre la superficie del agua de la Fuente, en el auto, y de la cual se enamora, quizá haya sólo un paso. Narciso concibe a la ninfa, en realidad su propio reflejo, como una deidad, a juzgar por las palabras de Liríope. El motivo dramático donde Narciso confunde a su reflejo con el de una mujer, no aparece en el mito narrado por Ovidio. Con todo, Louise Vinge hace referencia a un texto anónimo del siglo XV en el cual Narciso cree que la imagen reflejada sobre la superficie del agua es en realidad la de «una bella dama». La investigadora menciona también un enigmático y extenso poema ( Narciso, siglo XVII») escrito por el inglés Thomas Edwards, en el cual Narciso, vestido de mujer, se mira sobre la superficie del agua y cree de manera equivocada que su reflejo es el de una ninfa. Mientras la contempla, escucha la voz de Eco celosa y canta junto con ella ${ }^{34}$.

En Eco y Narciso, las acotaciones escénicas indican que Narciso cae y se transforma en flor. Por el contrario, en el auto, Narciso, identificado con Cristo, encarna en Naturaleza Humana y muere por ella para redimirla. Después de sumergirse en las aguas de la Fuente, emerge de ellas transformado, de manera simbólica, en la Hostia sobre un Cáliz, elementos visibles en escena, según las acotaciones.

Por último, destaco el recurso escénico del sonido de un terremoto -omitido en la fábula de Narciso narrada por Ovidio-, mediante el cual el dramaturgo representa la muerte de Cristo ${ }^{35}$. En Lo que va del hombre a Dios, Psiquis y Cupido, El socorro General y El Divino Orfeo, entre otras piezas teatrales, este recurso se utiliza, como en El Divino Narciso, junto con la evocación, en el espacio dramático, de un eclipse solar, en alusión al desorden cósmico producido por la muerte de Cristo, según los relatos bíblicos de Mateo, Marcos y Lucas (27, 45, $51 ; 15,33 ; 23,44)$.

${ }^{34}$ Ver Vinge, 1967, pp. 117, 174-175.

${ }^{35}$ Ver Arellano, 2000b, p. 213. 


\section{Conclusiones}

En Eco y Narciso y en El Divino Narciso, así como en otras obras de Pedro Calderón de la Barca y de sor Juana Inés de la Cruz, la trama, las relaciones entre los personajes y el asunto se compaginan con los espacios dramáticos que por su gran alcance simbólico trascienden el espacio escénico: son, en este sentido, espacios multifuncionales, en opinión de María Teresa Cattaneo, «de variada mimesis, de ambigua, oscilante significación ${ }^{36}$. Los símbolos en las obras aquí examinadas presentan, en efecto, un carácter polivalente.

Enrique Rull advierte acerca de la complejidad del paso de la comedia al auto, transposición realizada por Calderón en varias de sus obras tardías, la cual «no suele residir en la linealidad del argumento sino en algún elemento temático, ideológico o incluso escénico esencial para el posterior desarrollo de la alegoría que preside el género sacramental ${ }^{37}$. Quizá puedan aplicarse las palabras de Rull en lo referente al paso del drama de Eco y Narciso al auto de El Divino Narciso. La principal diferencia entre estas obras radica en el tratamiento que le da la jerónima al espacio dramático, mediante el recurso literario de la alegoría, el cual le permite explorar múltiples niveles de significación asociados con cuestiones religiosas, en particular con el Sacramento de la Eucaristía, de suma relevancia en el género del auto sacramental. Los temas principales de Eco y Narciso: la vanidad, la soberbia, el amor y la envidia, son pasados, en manos de la poetisa, por el tamiz de la religión cristiana; así lo exige el género del auto sacramental.

Sor Juana utiliza en su auto elementos alegóricos de la trama y de lo semántico, de Eco y Narciso; con todo, no representa, a mi juicio, una contrafacta del drama, en el sentido estricto del término. El Divino Narciso presenta, en efecto, una refundición de algunos símbolos, alegorías, y momentos dramáticos de la pieza teatral de Calderón e introduce a la vez ecos de distintos textos sacros y profanos. Podría decirse que le corta el vestido al drama de Calderón y crea, con el auto sacramental de El Divino Narciso, una confección de alta costura.

36 Cattaneo, 2003, p. 135.

37 Rull, 2004, p. 203. 


\section{BibLiOgRAFÍA}

Alciato, A., Emblemas, ed. S. Sebastián, Madrid, Akal, 1993.

Arellano, I., Estructuras dramáticas y alegóricas de los autos sacramentales de Calderón de la Barca, Kassel, Reichenberger, 2000a.

- Diccionario de los Autos sacramentales de Calderón, Kassel, Reichenberger, 2000b.

Bartra, R., El salvaje en el espejo, México, UNAM / Era, 1992.

Biblia de Jerusalén, Bilbao, Desclée de Brouwer, 1998.

Calderón de la Barca, P., OC, Eco y Narciso, t. II, ed. Á. Valbuena Prat, Madrid, Aguilar, 1967.

- La hija del aire, ed. F. Ruiz Ramón, México, Rei, 1990.

- Fieras afemina amor, Alicante, Biblioteca Virtual Miguel de Cervantes, 2001. Edición digital a partir de la Quinta parte de las Comedias de Don Pedro Calderón de la Barca, Barcelona, Antonio de Lacavallería, 1677.

- El Divino Orfeo, ed. J. E. Duarte, Kassel, Reichenberger, 1999.

Cattaneo, M. T., «Espacios ambiguos en el teatro de Calderón», en Loca Ficta: los espacios de la maravilla en la Edad Media y Siglo de Oro, ed. I. Arellano, Madrid / Frankfurt, Iberoamericana / Vervuert, 2003, pp. 125-136.

Cirlot, J. E., Diccionario de símbolos, Madrid, Siruela, 1997.

De la Cruz, sor J. I., El Divino Narciso, OC, t. III, ed. A. Méndez Plancarte, México, FCE / Instituto Mexiquense de Cultura, 1995.

Del Río Parra, E., Una era de monstruos: representaciones de lo deforme en el Siglo de Oro español, Madrid / Frankfurt, Iberoamericana / Vervuert, 2003.

Diccionario de la Biblia, Barcelona, Herder, 1987.

GuÉNON, R., "La caverne et le labyrinthe», en Les symboles fondamentaux de la Science sacrée, Paris, Garnier, 1962, pp. 150-169.

Hatzfeld, H., Estudios literarios sobre mística española, Madrid, Gredos, 1976. Kristeva, J., Historias de amor, México, Siglo xxi, 2004.

McKendrick, M., "El espacio simbólico en Calderón», en Archivum Calderonianum: Hacia Calderón, Noveno Coloquio Anglogermano, ed. H. Flasche, Stuttgart, Steiner Verlag, 1990, pp. 25-56.

Osorio, I., Conquistar el eco: la paradoja de la conciencia criolla, México, Coordinación de Humanidades / UNAM, 1989.

Ovidio, Las metamorfosis, ed. R. Bonifaz Nuño, México, Secretaría de Educación Pública, 1985, vol. 1.

Parker, A. A., "The Calderonian Sources of El Divino Narciso», Romanistisches Jahrbuch, 19, 1968, pp. 257-274.

Pérez de Moya, J., Filosofía secreta de la gentilidad, ed. C. Clavería, Madrid, Cátedra, 1995.

Petelin, J., «Raíces de la Maestra Sabiduría», Revista Bíblica, 46, 1984, pp. 343355. 
Regalado, A., Los orígenes de la modernidad en la España del Siglo de Oro, Barcelona, Ediciones Destino, 1995, 2 vols.

Rull, E., Arte y sentido en el universo sacramental de Calderón, Kassel, Reichenberger, 2004.

VAREy E. J., Cosmovisión y escenografía: el teatro español en el Siglo de Oro, Madrid, Castalia, 1987.

VInge, L., The Narcissus Theme in Western European Literature up to the Early 19 th Century, Lund, Gleerups, 1967.

Wardropper, B., Historia de la poesía lírica a lo divino en la cristiandad occidental, Madrid, Revista de Occidente, 1958. 